\title{
Dealing with all types of quotations (and their parallels) in a closed corpus: The methodology of the Project The literary tradition in the third and fourth centuries CE: Grammarians, rhetoricians and sophists as sources of Graeco- Roman literature
}

\author{
Lucía Rodríguez-Noriega Guillén \\ University of Oviedo, Spain \\ Inoriega@uniovi.es
}

\begin{abstract}
The Project The literary tradition in the third and fourth centuries CE: Grammarians, rhetoricians and sophists as sources of Graeco-Roman literature (FFI2014-52808-C2-1-P) aims to trace and classify all types of quotations, both explicit (with or without mention of the author and/or title) and hidden, in a corpus comprising the Greek grammarians, rhetoricians and "sophists" of the third and fourth centuries CE. At the same time, we try to detect whether or not these are first-hand quotations, and if our quoting authors (28 in all) are, in turn, secondary sources for the same citations in later authors. We also study the philological (textual) aspects of the quotations in their context, and the problems of limits they sometimes pose. Finally, we are interested in the function of the quotation in the citing work. This is the first time that such a comprehensive study of this corpus is attempted. This paper explains our methodology, and how we store all these data in our electronic card-file.
\end{abstract}

\section{Keywords}

Intertextuality; fragmentary literature; Greco-Roman scholars of the Empire.

\section{INTRODUCTION. THE PROJECT AND ITS MAIN AIMS}

The Project The literary tradition in the third and fourth centuries CE: Grammarians, rhetoricians and sophists as sources of Graeco-Roman literature II (http://www.Inoriega.es/Fuentes.html) is funded by the Spanish Ministry of Economy and Competitiveness (reference FFI2014-52808-C2-1-P). At the moment, it involves eight researchers from the University of Oviedo, Spain (Lucía Rodríguez-Noriega Guillén, main researcher; Manuel González Suárez; Luis Alfonso Llera Fueyo; Virginia Muñoz Llamosas; Abigail Torre Beivide; Javier Verdejo Manchado), the University of the Basque Country, Spain (María José García Soler), and the University of Bari Aldo Moro, Italy (Piero Totaro). The Project also has an external collaborator, the computer engineer Patricia Conde Clemente, currently a PhD Research Fellow at the University of Oviedo, who is responsible for advising and developing computing tasks. A coordinated project, based at the University of Zaragoza and headed by Professor Javier Uría Varela, studies quotations in the Latin grammarians of the same period. Both projects have been granted funds for a second period of three years, finishing 31/12/2017.

The aim of the Project is to examine the Graeco-Roman literary tradition in the third and fourth centuries $C E$ by means of the compilation, analysis of and commenting on the quotations in the works of the grammarians (i.e. the authors of grammars, lexicographers and writers on literary and linguistic subjects in general) and rhetoricians of the time, and of those contemporary prose writers traditionally called "Greek Sophists". Until now, such a comprehensive study of this corpus has never been attempted. The Project deals with all types of quotations, and besides analysing and commenting on the quotes, tries to trace their parallels in both previous and later authors. This can 
help us to determine whether we are dealing with first hand or mediate quotations, and whether or not our authors were, in turn, the intermediate sources through which the same passage was known and later quoted.

The selection of authors and period is not random. Grammarians, rhetoricians and sophists very frequently quote other authors; hence, in their works there is always an abundance of testimonies and fragments from philosophers, poets, grammarians, orators, historians, etc. In addition, the Greek writers of the third and fourth centuries CE were, at that time, still able to access many works which have not been handed down to the present day by direct manuscript transmission. In addition, they constitute a group of 28 authors in all, making them a suitable corpus to be studied in a realistic time frame by a team of eight researches like ours. This is their list:

- Aelianus sophista ( 3 rd century CE)

- Apsines rhetor ( 3 rd century CE)

- Athenaeus Naucratites grammaticus (2nd-3rd centuries CE)

- Autochthon grammaticus (3rd century CE)

- Callistratus sophista (4th century CE)

- Eudaemon grammaticus (RE n. 8, 4th century CE)

- Genethlius grammaticus (RE n. 2, 3rd century CE)

- Helladius grammaticus (4th century CE)

- Himerius sophista (4th century CE)

- Libanius sophista (4th century CE)

- Longinus, Cassius, rhetor et philosophus (3rd century CE)

- [Longinus] de Sublimitate

- Lupercus grammaticus (RE n. 5, 3rd century CE)

- Menander rhetor (3rd century CE)

- Metrophanes grammaticus (RE n. 4, 3rd-4th centuries CE)

- Nicocles grammaticus (RE nrs. 9, 1, 4th century CE)

- Philemon grammaticus (RE n. 14, 2nd-3rd centuries $C E$ )

- Philostratus sophista (2nd-3rd centuries CE)

- Philostratus lunior sophista (3rd century CE)

- Philostratus Maior sophista ( $3 r d$ century CE)

- Pius grammaticus (2nd-3rd centuries CE)

- Polemon grammaticus (RE n. 12 , 4th century CE)

- Porphyrius Tyrius (3rd century CE)

- Themistius sophista (4th century CE)

- Theodosius Alexandrinus grammaticus (4th century CE)

- Timaeus grammaticus (4th century CE)

- Troilus grammaticus (4th century CE)

- Ulpianus grammaticus (4th century CE)

(see also http://www.Inoriega.es/Autorescitantes.html). 


\section{STATUS QUAESTIONIS}

One of the richest fields within literary studies is that of intertextuality, understood as the interrelationship between a certain literary work and others, whether contemporary, previous or subsequent, and whether an explicit (literal or allusive) or implicit reference is implied. The detection and study of these relationships is essential, for instance, to reach sound conclusions on the influence exerted by their cultural tradition on every writer in every generation, and to achieve comprehensive knowledge of the survival and circulation of the texts and the ideas they transmit throughout history.

In the particular case of Ancient Greek literature, there is in addition a special feature, which increases the interest of studies of intertextuality. In fact, up to the present times Greek literary texts have suffered a long and hazardous transmission, as a consequence of which only a very small part of them has come down to us by direct manuscript tradition, while many more have been lost through the centuries. This type of approach is thus especially important to recover quotations and testimonies of works that are only known by indirect transmission.

Classical scholars have traditionally paid considerable attention to the mutual relationships between authors, especially poets, and dedicated numerous studies to the sources of many writers. In the particular case of the 28 authors studied by our Project we might mention, for instance, though the list is far from exhaustive, the contributions by [Rudolph, 1884], [Cohn, 1886], [Rudolf 1894], [Stefani 1912], [Glombiowski, 1986], [Schettino, 2004] and [Prandi, 2005] on Aelian's sources; those on the sources of Athenaeus of Naucratis by [Bapp, 1885], [Bapp, 1888], [Rudolf, 1891], [Cohn, 1894], [Rudolf, 1894], [Ambaglio, 1990], [Zecchini, 1989], [Hill, 1995], [Villari, 1996], [Bowie, 2000], [Sidwell, 2000], [Quaglia, 2001], [Jacob, 2004], [Cipolla, 2006] and the papers gathered in [Lenfant, 2007]; those on Philostratus' sources by [Breloer, 1939], [Norman, 1953], [Keil, 1953], [Szarmach, 1973], [Blanchard, 1986], [Suárez de la Torre, 1991], [Dickie, 1997], [Mangia, 2001], [Zeitlin, 2001], [Librán Moreno, 2005], and [Librán Moreno, 2006]; those on Philostratus Iunior's sources by [NoackHilgers, 1999], [Gallé Cejudo, 2000], and [Gallé Cejudo, 2001]; those on Himerius' sources by [Mesk, 1922], [Meerwaldt, 1954], [Papadimitriou, 1971-72], [Cuffari, 1983], [Colonna, 1993], and [Lazzeri, 2002]; those on Libanius' sources by [Middleton, 1919-1928], [Norman, 1964], [Schouler, 1984], [Rivolta Tiberga, 1989], [García Soler, 1990], [García Soler, 199192], and [López Eire, 1993]; those on Longino's sources by [Apfel, 1935], [Ruckh, 1943], [Sedgwick, 1948], [Mazzuchi, 1988], [Dyck, 1989], and [Morenilla Talens, 1996]; those on Themistius' sources by [Volpe Cacciatore, 2005] and [Maisano, 2006]; and those on Porphyry's sources by [Sodano, 1965], [Pépin, 1965] and [Sodano, 1965-66].

Nevertheless, many of these studies are partial and most of them have been carried out without a clear, well stablished methodology based on modern research on intertextuality (some are in fact too old to have benefitted from the new approaches to the subject). Among the most important works on intertextuality since the end of the 20th century to the present day which affect the theoretical background of our Project are [Compagnon, 1979], [Reyes, 1984], [Reyes, 1993], [Reyes, 1996], [Fraser, 1990], [Schiffrin, 1987], [Coulmas, 1986], [Most, 1997], [Rosier, 1999], [Récanati, 2000], [Darbo-Peschanski, 2004], and [Nicolas, 2005].

New approaches to the study of intertextuality based on ICT have also flourished in recent years. But, as the international workshop held in Lyon in 2014 (see 
http://biblindex.hypotheses.org/1686) and this volume itself make clear, despite the increasing interest in sharing experiences to date no methodology or electronic tool able to meet the needs of all the groups working on corpuses written in ancient languages has been developed. Thus, our team is carrying out its own experiment, following a methodology we will expound on in the next section.

\section{THE METHODOLOGY OF THE PROJECT}

\subsection{Introductory remarks}

As our Project was conceived of as long term, and taking into account the huge quantity and variety of data we had to deal with, the need to stablish a uniform and systematic work procedure was clear from the beginning. Our methodology involves first the gathering of all the quotes that can be traced in a given work, and then their analysis in accordance with a detailed and carefully planned protocol, with the help of an electronic card, which has been designed and improved as the work has progressed and the team has gained experience.

\subsection{The lists of quotes}

The task of searching for quotations is preceded by a thorough study of the quoting author and his work, and the history of the text. For every work we principally use the canonical printed edition, but often consult others, and we also take into account all the relevant bibliography.

Every member of the team deals with one or more quoting authors or works, depending on their personal tastes and interests, but also on the length of the work to be studied, and the time each person has at their disposal. Every researcher first makes a complete list of the quotations found in the assigned work, following the order of the passages in the quoting text. Quotes are searched for by direct reading of the quoting text (even if the edition has a final list of quoted authors or works), but we also take into account all previous studies on the quoting author's sources, and material such as the lists of sources included in the editions of fragmentary authors of all types. This list is then published on our website (Figure 1). Active links in the list of quoting authors

(http://www.Inoriega.es/Autorescitantes.html) indicate that we have published a complete list of quotations for at least one of that author's works. Each time we indicate the name of the researcher in charge of the quotes for that particular work or author, the edition we base the study on, the exact number of quotations found, and various other data. Thus far the Project has listed 6623 quotes in all, but there are still 7 authors whose quotes have not yet been gathered, and for some of these (specifically Aelian, Libanius, Philostratus and Porphyry) not all works have a list of quotes already prepared. We expect to publish the complete list of quotes of the first 5 books of Athenaeus Deipnosophist in the first semester of 2016.

In the second phase, the original list is rearranged according to the quoted authors, in alphabetical order of author and work. Then these data are combined with those coming from the rest of the team, in order to make separate lists of quotations according to the quoted authors. These lists are also published on line in the corresponding section; see

http://www.Inoriega.es/AutorescitadosA C.html; http://www.Inoriega.es/AutorescitadosD I.html; http://www.Inoriega.es/AutorescitadosL Z.html.

Unlike in the case of the quoting authors, the catalogue of quoted authors is still open and provisional, and so, of course, are the corresponding lists of quotations. Up to now, we have found quotations from more than 400 authors, both Greek and Roman. 

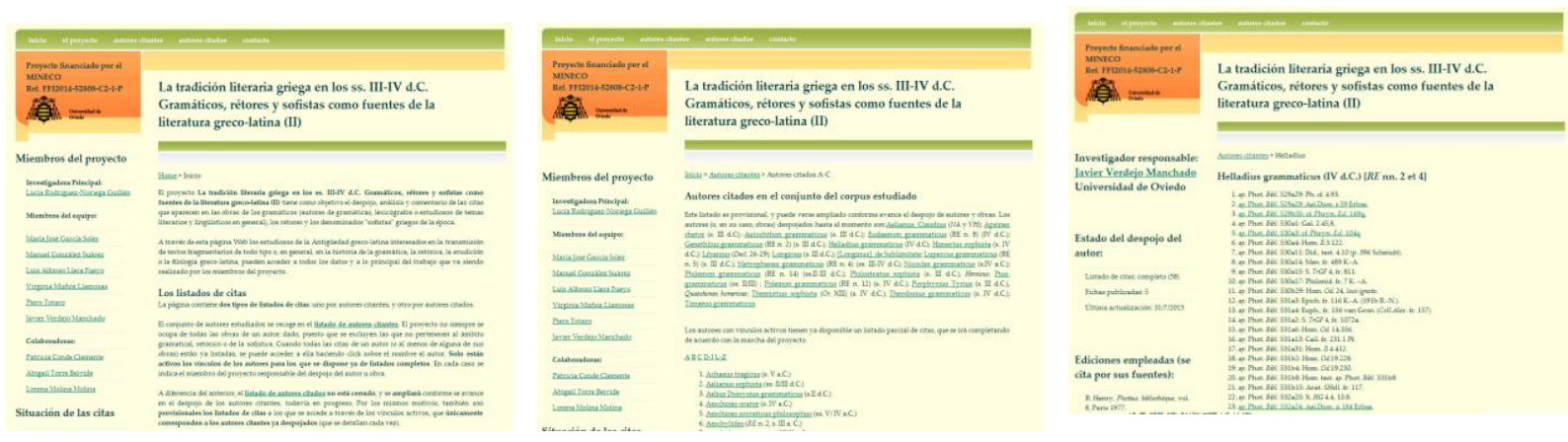

Figure 1. The Project web site.

\subsection{The study of the quotes}

As we make the lists of quotes, we also proceed to the analysis of the individual quotations. Over the first two years of work (2011-2012), the team, based on the researchers' experience, developed a working protocol, according to which every single quote originates an electronic card, with several key-fields. As we will see, our analysis of every quote is very thorough, and every card runs to several pages. As a result, the publication of the cards advances at a much slower pace than that of the lists of quotes. The results of this part of our study are also published on line in single PDF files; the number of cards published thus far (February 2016) is 158.

The electronic card key-fields are the following:

- Quoting author - Century - Quoting work - Passage

- Quoted author - Century - Quoted work - Passage

- Typology of the quotation

- Direct/ Indirect quote (with or without explicit indication of the source; right/wrong/dubious adscription)

- Literal quote/ Paraphrase/ Imitation/ Parody/ Lax reference/ Mere mention of the author's name or of the work's title /Hidden quote

- Introductory expression

- Greek text

- Critical apparatus

- Reason for the quotation

- Spanish translation

- Parallel mentions in the same author/ in previous authors/ in contemporary authors/ in subsequent authors. In all three cases the following fields are also included:

○ Quoting author - Century - Quoting work - Passage

- Greek text

- Critical apparatus

- Reason for the quote

First of all, we record the data concerning the quoting author (name, century, work and passage where the quotation is found) and then, those corresponding to the quoted author (also name, century, work and passage). If the quoted author does not have an edition of his or her own, we mark the passage as "fragmentum nondum editum" or "nondum excerptum", and as "fragmentum novum" if it has passed unnoticed by editors up to the present. Mentions and testimonies regarding the authors and their lives are usually impossible to refer to any edition when they concern authors known by direct manuscript transmission, because in such cases, unlike in that of the fragmentary ones, editions do not usually include a section of "testimonies". In these cases, the reference of the quotation on the website may include a 
brief description of the content of the quotation, if appropriate (for instance "de vita", "de fama", etc.).

Next we indicate 1) whether or not the quotation is explicitly assigned to an author in the quoting text, 2) if the assignment is right, wrong or doubtful, and 3) whether or not the quote has an intermediary source also mentioned in the text, or whether it can be identified by other means (in which case we refer to the "parallel mentions" section). The latter is, in fact, one of the questions the Project is most interested in. To try to determine whether we are dealing with a secondary (i.e. second-hand) quotation when the author does not openly say so, we take into account, besides what we can deduce from the reading of the text itself, what is known about the author, his literary education and the libraries he might have had access to, and also about the preservation and transmission of the quoted text in the third and fourth centuries CE. The search for quotations of the same passage in previous authors can also, with appropriate analysis, be helpful to find intermediate sources from which the quotation has been taken, if that be the case.

Next on the card we classify the quotation, indicating if it is 1) a literal quotation; 2) a paraphrase; 3) an imitation; 4) a parody; 5) a lax reference; 6) a mere mention of an author's name or of a work's title; or 7) if the quoting author is using previous material hiding the fact that it is a quote. This classification has been developed by the members of the team in line with their practical experience, but of course also taking into account many previous studies (see section I above), of which [D’Ippolito, 1983] has been especially inspiring.

A literal quotation tries to reproduce the original text verbatim, but does not need to be exact. Thus, we also consider it a literal quotation if the quoting author chose to shorten some intermediate parts of the original text for some particular reason, being accurate for the rest. Or if he made some slip-up when quoting from memory, but still believed himself to be reproducing the quote in the right form.

A paraphrase implies a re-wording of the original text, while keeping its essential content. A very common type of paraphrase consists in rendering poetry texts in prose, a procedure that some ancient rhetoricians recommended in order to adapt the quote to the style of the quoting author.

Imitations, parodies, allusions and hidden quotations in general are sometimes difficult to distinguish from what [D'Ippolito, 1983: 327-328] calls "generic references", that is, literary allusions which belong to Greek cultural heritage in general, and cannot be considered references to any concrete work or author. On determining this, the researcher's personal judgment plays a very important, and irreplaceable, role. For the identification of hidden quotations, we rely on the direct reading of the original text, taking into account the apparatus of loci similes if the edition has one, but we also consult previous studies of the author's sources, if there are any available. Good annotated translations and commentaries are often also useful for this task, as too are the searches for key-words by means of the [Thesaurus Lingua Graecae ${ }^{\circledR}$ Digital Library] (hence $T L G$ ). As for explicit quotations, they have often already been identified in the editions of the quoting authors, but the references and indexes in those editions are sometimes incomplete, outdated or faulty, so even in these cases we proceed as in those of hidden quotations.

We also record the expression that introduces the quotation, which can be useful to establish the author's quoting habits (certain expressions, for instance, can point to mnemonic quotations, others, 
to quotes by reading, etc.). In addition, we think that a stock list of introductory expressions can, in the long run, be useful to trace new quotations in a given corpus by computational means.

The next two fields in the electronic card are the text of the quotation, and the critical apparatus. The text includes the quotation's context, which is essential to the correct understanding and assessment of the quote. The textual analysis is made from the point of view of the quoting author, so what we try to reproduce is the text of the quotation in the way it was known to the quoting author, or in the way he chose to quote it; therefore, our text of the quote may differ from the one that can be read in the quoted author's edition. Through all this process, we use one or more editions of both the quoting and the quoted author. More specifically, when a literal quotation can be compared with other sources, either direct or indirect, and there are differences between them, it is important to determine if the divergence is due to:

- A scribal error arising in the course of the manuscript transmission of the quoting text, which must, therefore, be corrected (errors due to iotacism, confusion of similarly shaped letters, errors of accentuation, incorrect word division, etc.).

- The author being quoting from memory.

- A deliberate change made by the quoting author for whatever purpose.

- The existence of an ancient variant reading in the text consulted by the quoting author. In the three latter cases, we reproduce the author's version of the quote as it is, without emending it.

In addition, when dealing with fragmentary authors the problem sometimes arises of determining the boundaries between quoting and quoted text, which is not always obvious. Here we can resort to syntactic, stylistic and content criteria, and also to comparisons with parallel quotations in both previous and later writers.

Next, we offer a Spanish translation of the quotation and its context. As passages taken out of their original context are often difficult to understand, the translation may provide a helpful starting point for the reader, especially if they do not have the complete original text to hand.

Another aspect we are interested in is the function of the quote within the quoting text, so we have included on the card another field where we analyse the reasons why that particular passage was quoted at that particular point of the work. Some quotations prove to be merely ornamental, and others are mainly means to show the quoting author's culture or erudition. However, many others are essential for the purposes of the work; for instance, in discourses and argumentative texts in general quotes are often used to support theses or arguments, and in many grammatical treatises they are adduced because they provide the examples to illustrate the point under discussion. Some quotes are also adduced with a humorous purpose (thus the parodies, but not only them).

In another section of the card we indicate if the same quotation appears in other works by the same author, or in other passages of the same work. If that is the case, we refer the reader to the corresponding card.

The next three sections are very important to us, because in them we record occurrences of the same quotation in other previous, contemporary or subsequent authors. We register, first, the author, century, work and passage where the same quotation is found. Then we comment on the similarities and differences between the quotations. Finally we record the relationships between the respective authors, indicating if both 1) read the quotation directly in the original work, 2) share the same indirect source, 3) follow independent traditions, or if 4) there is a direct relationship between them, that is, if one author is the indirect source from which the other took the quotation. 
The search for those parallel quotations can be aided by the apparatuses of loci similes if the editions have any, and by previous studies on the author's sources, but the Project also carries out searches by means of the $[T L G]$, through searches for keywords. In the searches we take into account the possible variants of the inflected words, because our experience has demonstrated that, among the many alterations quotes may suffer, one of the most common is the alteration of their syntax to accommodate them to the new context, or simply to turn them into more rounded sentences.

The study of every quotation is completed with a commentary, where we analyse and discuss all relevant information concerning the quotation, its context, its parallels, etc. The length of this field varies a lot, depending on the interest of the passage studied.

Finally, there is a section of conclusions on the position and relevance of our author regarding the transmission of the quoted text.

Every card includes a bibliographical note, the name and affiliation of its author, and the date when it was last updated.

\subsection{The "e_Fichas" application}

To give support to the methodology we have just described, the team has designed a desktop application called "e_Fichas" (see Figure 2) in C\# language, under the .Net 4.0 Framework. The application allows the creation and modification of the electronic cards (one for each quotation), which are stored individually in XML 1.0 format, and eventually exported to PDF format in order to publish them on our website. The Project members store the generated cards in a shared folder on the network by using a file transfer utility.

To upload and store the XML data the application uses the DataSet component, which performs these operations in a transparent way. The various fields on the record are stored in Rich Text Format (RTF) or plain text. RTF is used in those fields where it is necessary to give a special format to a piece of text, such as writing in Greek, place text in italic or bold, or include a superscript.

As we have already mentioned, after the insertion of the data corresponding to every card, the application allows the user to export them to a PDF file (a Word-file is also automatically generated together with the PDF file), which is then published in the static website http://www.Inoriega.es/Fuentes.html, which is open source.
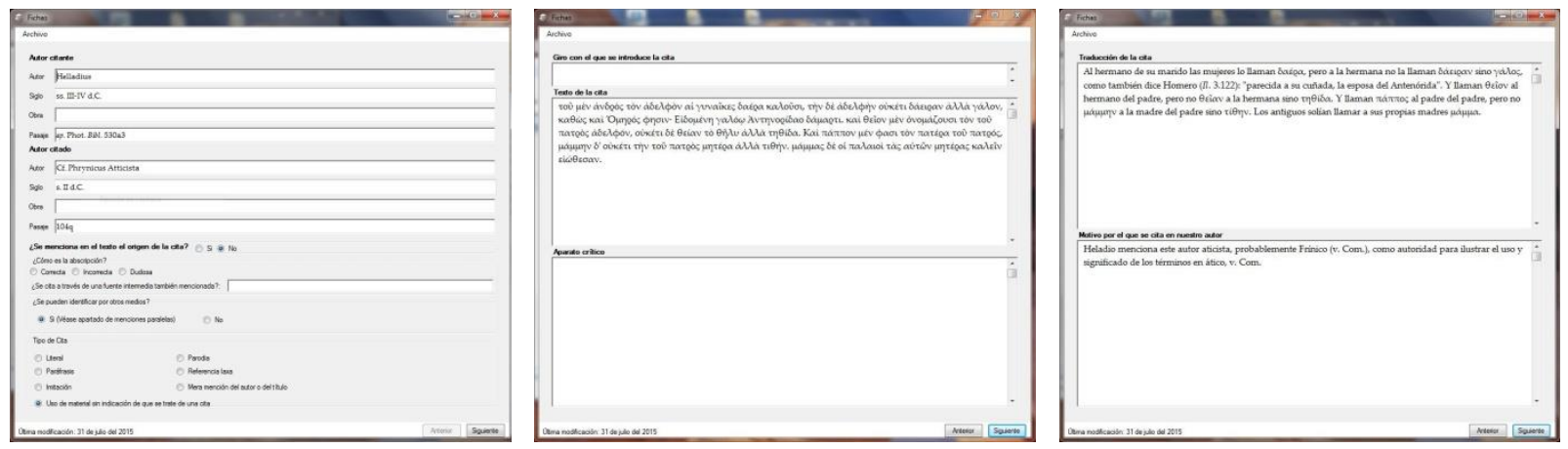

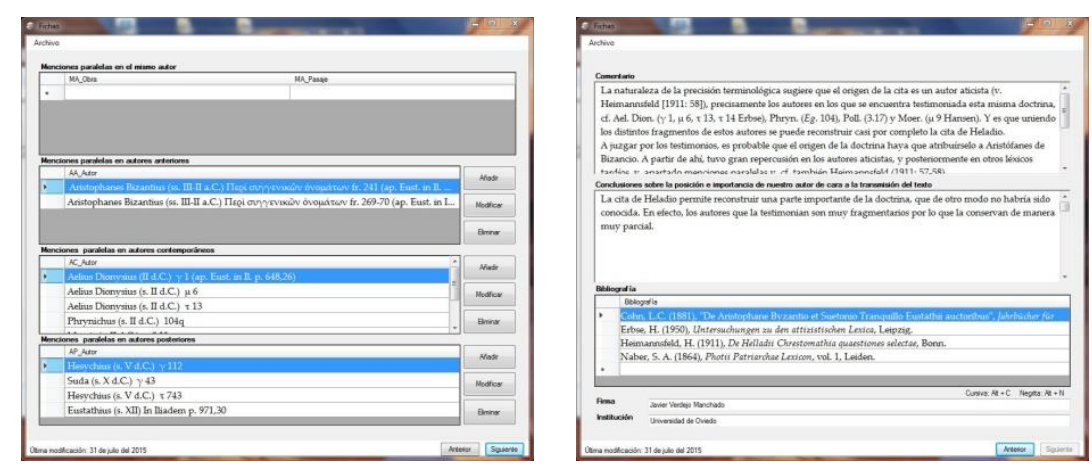

Figure 2. e_Fichas desktop application.

\section{CONCLUSIONS}

Through the analysis of this corpus in search of all type of quotations and their subsequent study we can:

- Determine which authors were still directly read in the third and fourth centuries CE, and which works were still quoted, but no longer read, and find networks of relations among writers.

- Discover new testimonies and fragments, which may have passed unnoticed by editors for different reasons, or call fresh attention to them, if the author is only quoted by his sources, and has not an edition of his/her own.

- Contribute a different viewpoint to the study of fragmentary texts, on analysing them from the perspective of the quoting author.

- Help to a better appraisal of the textual variants in fragmentary texts transmitted by several sources, if relations of interdependency among these sources can be traced.

- Help to improve the text of the quoting authors.

- Establish an overall view, which, based on the study of the sources and using the passages of each specific author, provides in-depth information and shows us how much these intellectuals as a group knew of their own cultural history, and how important this material - especially the fragments - is in the preservation of Graeco-Latin literature.

- Place the results of this research in the hands of the scientific community as open source on-line reference material, thus allowing those scholars interested not only in the transmission of every type of fragmentary text, but also in Grammar, Rhetoric, Learning and Graeco-Latin Philology, access to all the details and the main conclusions of the work carried out by the members of the research team.

Using the web site and the e_Fichas application, we cover three main objectives. Namely to:

- Provide Project members with an application that will guide them and facilitate the analysis process and the management of data (create, open, save, edit and export).

- Store information in a way that makes its management easier.

- Give all users access, via the website, to the lists of quotations (according to both the quoting and quoted authors) and to the respective cards (currently in PDF format).

\section{THINKING AHEAD}

As we have already said, for now the Project publishes the lists of quotations and the corresponding cards on a static website. In the medium term, however, we mean to develop an electronic tool able 
to store, handle and analyse the data in an automatic, dynamic and efficient way. In what follows, we will identify the step-wise leading to achieve that final aim:

- Digitisation.

- Establish a working method for the digitisation of the field material.

- Create a database with electronic cards using the standard TEI. Cards will include metadata to facilitate the semantic searches typical of Web2.0.

- Convert the present static electronic cards to the new format.

- Innovative use of electronic tools and statistics for the treatment of the digitised data.

- Create a dynamic website, which allow access to the digital content.

- Create a smart search engine for the cards.

- Create an analyser module, which shows in a graphic and intuitive way the relationships between authors and quotes, by applying advanced methods of social network analysis.

The graphical analysis of the information would be based on the methodology for bibliometric studies proposed by [Moya Anegón et al., 2004], [Moya Anegón et al., 2007] and [Vargas Quesada and Moya Anegón, 2007]. These authors have developed a new technique for building maps of large scientific domains based on the co-citation of works [Salton and Bergmark, 1979].

We would like to adapt the proposed methodology to our field of study, by developing several metrics of co-citation based on the electronic cards stored in the database. Each metric would allow us to obtain a matrix of co-citations, which would link quoting and quoted authors, works, quotes, etc. All the content of the matrix would be represented in a map, which could be analyzed automatically by using techniques for social networks analysis [Scott, 2000] and [Wasserman and Faust, 1994]. As a result, dynamic graphical representations would be generated, according to the criteria set by the user. This would allow to see the conclusions derived from a detailed bibliometric analysis in a fast and intuitive way. It would also offer an innovative and complementary view to conventional statistical analysis.

\section{References}

Ambaglio D. I Deipnosofisti di Ateneo e la tradizione storica frammentaria. Athenaeum. 1990;78:51-64.

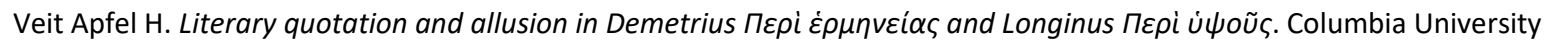
Press (New York), 1935.

Bapp C.A. De fontibus quibus Athenaeus in rebus musicis lyricisque enarrandis usus sit. LSKPh. 1885;8:85-160.

Bapp C.A. Beiträge zur Quellenkritik des Athenaeus [1. Pamphilus. 2. Seleucus]. Teubner (Leipzig), 1888:251-265.

Blanchard M.E. Problèmes du texte et du tableau. Les limites de l'imitation à l'époque hellénistique et sous l'empire. Cassin

B. and Blanchard M.E. Le plaisir de parler: Études de sophistique comparée. Les Éditions de Minuit (Paris), 1986:131-154.

Bowie E.L. Athenaeus' Knowledge of Early Greek Elegiac and lambic Poetry. Braund D. and Wilkins J. Athenaeus and his World. Exeter University Press (Exeter), 2000:124-135.

Breloer B. Drei unbenannte Megasthenesfragmente über die pravrajya. ZDMG. 1939;93:254-293.

Cipolla P. Le citazioni dei tragici in Ateneo. Studi sul Teatro Greco. Hakkert (Amsterdam), 2006:79-136.

Cohn L. Besprechung von F. Rudolph, De fontibus quibus Aelianus in varia historia componenda usis sit. Philologische Anzeiger. 1886:16:96-103.

Cohn L. Zu den Quellen des Aelian und Athenaeus. Philologus. 1894;52:722-725.

Colonna A. Una testimonianza eschilea in Imerio: T 150 Radt. Paideia. 1993;48:104.

Compagnon A. La seconde main ou le travail de la citation. Éditions du Seuil (Paris), 1979.

Coulmas F. Direct and Indirect Speech. De Gruyter (Berlin), 1986.

Cuffari G. I riferimenti poetici di Imerio. Università di Palermo (Palermo), 1983.

Darbo-Peschanski C. La citation dans l'Antiquité, Actes du colloque du PARSA. Jérôme Millon (Grenoble), 2004.

Dickie M.W. Philostratus and Pindar's eighth Paean. BASP. 1997;34:11-20.

Dyck A.R. New light on Greek authors from grammatical texts. MH. 1989;46:1-8.

Fraser B. An approach to discourse markers. Journal of Pragmatics. 1990;14:383-395. 
Gallé Cejudo R.J. La exégesis homérica en la paráfrasis filostratea del escudo de Aquiles (Philostr. Jun. Im. 10.4-20 - Hom. II.18.478-608). X congreso español de estudios clásicos, vol. 1. Ediciones Clásicas (Madrid), 2000:409-414.

Gallé Cejudo R.J. El escudo de Neoptólemo: la paráfrasis filostratea del Escudo de Aquiles (Philostr. Jun., «Im.» 10.4-20 Hom., "ll.» 18.483-608. Universidad de Zaragoza (Zaragoza), 2001.

García Soler M.J. Reflejos de la comedia ática en la declamación XXVI de Libanio. Veleia. 1990;7:265-291.

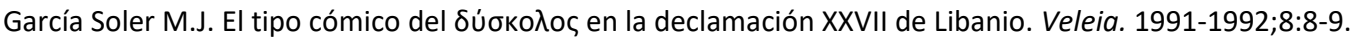

Glombiowski K. Fragments de Ctésias de Cnide chez Diodore et chez Élien non cités par Jacoby (FGrHist. 688). Eos. 1986;74:77-88.

Hill S. The Sources and Sauces of Athenaeus. Wilkins J., Harvey D. and Dobson M. Food in Antiquity. Exeter University Press (Exeter), 1995:429-438.

Keil J. Vertreter der zweiten Sophistik in Ephesos. JCEAI. 1953;40:5-26.

Jacob C. Athenaeus the Librarian. Braund D. and Wilkins J. Athenaeus and his World. Exeter University Press (Exeter), 2000:85-110.

Lazzeri M. Imerio e la «Palinodia» di Stesicoro. SemRom. 2002;5 (2):169-179.

Lenfant D. Athénée et les fragments d'historiens. De Boccard (Paris), 2007.

Librán Moreno M. Philostr. Her. XXXV 9-10: ¿un testimonio de Eurísaces de Sófocles? Emerita. 2005;73(1):119-143.

Librán Moreno M. Philostr. Her. 20.2 : una posible alusión a El juicio de las armas de Esquilo. CFC(G) 2006;16:195-209.

López Eire A. Las citas homéricas en las Epístolas de Libanio. Habis. 1993;24:159-177.

Maisano R. Patrimonio culturale «di prima mano» e «di seconda mano» nei «Discorsi» di Temistio. Amato E. Approches de la Troisième Sophistique: hommages à Jacques Schamp. Latomus (Bruselas), 2006:477-481.

Mangia C. Quattro nuove testimonianze su Callistene di Olinto. AFLB. 2001;44:361-377.

Mazzuchi C.M. Tre citazioni adespote nel Sublime. Aevum(ant). 1988;1:223-232.

Meerwaldt J.D. Epithalamica I: De Himerio Sapphus imitatore. Mnemosyne. 1954;7:19-38.

Mesk I. Sappho und Theocrit in der ersten Rede des Himerios. WS. 1922;44:160-170.

Middleton G. Studies in the orations of Libanius. Aberdeen University Press (Aberdeen), 1919-1928.

Morenilla Talens C. Los textos a través de los textos: Esquilo en el «De sublimitate». IX Congreso español de estudios clásicos, vol. 4. Ediciones Clásicas (Madrid), 1996:259-263.

Most G.W. Collecting Fragments - Fragmente sammeln. Vandenhoek \& Ruprecht (Gottingen), 1997.

Moya Anegón F., Vargas Quesada B., Herrero Solana V., Chinchilla Rodríguez Z., Corera-Álvarez E., and. Muñoz Fernández F. $J$, A new technique for building maps of large scientific domains based on the cocitation of classes and categories, Scientometrics, 2004;61(1):129-145.

Moya Anegón F., Vargas Quesada B., Chinchilla-Rodríguez Z., Corera Álvarez E., Muñoz Fernández F. J. and Herrero Solana V. Visualizing the marrow of science. Journal of the American Society for Information Science and Technology. 2007; 58(14):2167-2179.

Nicolas C. Hôs ephat', dixerit quispiam, comme disait l'autre... Mécanismes de la mention et de la citation dans les langues de l'Antiquité. UFR de lettres classiques et modernes, Université Stendhal (Grenoble), 2005.

Noack-Hilgers B. Zur Rezeption der homerischen Gerichtsszene im 3. Jh. n. Chr. und zu ihrer juristischen Umdeutung. ZRG. 1999;116:1-24.

Norman A.F. Philostratus and Libanius. CPh. 1953;48:20-23.

Norman A.F. The library of Libanius. RhM. 1964;107:158-175.

Papadimitriou I. Th. Some echoes of Thucydides in Himerius' Orationes. Helikon. 1971-1972;11-12:469-473.

Pépin J. Pophyre, exégète d'Homère. Porphyre: huit exposés suivis de discussions, Fondation Hardt (Vandœuvres-Genéve), 1965:229-272.

Prandi L. Memorie storiche dei Greci in Claudio Eliano. L'Erma di Bretschneider (Roma), 2005.

Quaglia R. Citazioni da Aristofane e dalla Commedia Antica in Ateneo. Maia. 2001;54(3):611-633.

Récanati F. Oratio obliqua, oratio recta. An essay on Metarepresentation. MIT (Cambridge, Mass.), 2000.

Reyes G. Polifonía textual. La citación en el relato literario. Gredos (Madrid) 1984.

Reyes G. Los procedimientos de cita: estilo directo y estilo indirecto. Arco libros (Madrid), 1993.

Reyes G. Los procedimientos de cita: citas encubiertas y ecos. Arco libros (Madrid), 1996.

Rivolta Tiberga P. Ideologia e comunicazione: I'impiego della citazione classica in Libanio. Garzya A. Metodologie della ricerca sulla tarda antichità. Atti del primo convegno dell'Associazione di studi tardoantichi. D'Auria (Naples), 1989:493509.

Rosier L. Le discours rapporté. Histoire, théories, pratiques. Duculot (Paris), 1999.

Rudolph F. De fontibus quibus Aelianus in varia historia componenda usus sit. LSKPh. 1884;7:1-138.

Rudolph F. Die Quellen und die Schriftstellerei des Athenaios. Philologus. 1891;Suppl. 6:109-162.

Rudolph F. Zu den Quellen des Aelian und Athenaios. Philologus. 1894;52:652-663.

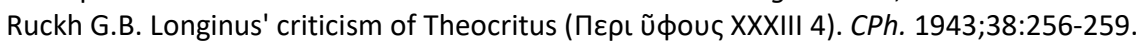

Salton G. and Bergmark D. A citation study of computer science literature, IEEE Transactions on Professional Communication. 1979;22:146-158.

Schettino M.T. Il passato e il presente di Roma nell'opera di Eliano. Troiani L. and Zecchini G. La cultura storica nei primi due secoli dell'impero Romano. L'Erma di Bretschneider (Roma), 2004:283-307.

Schouler B. La tradition hellénique chez Libanios. Atelier Nat., Reproduction des Théses (Paris), 1984.

Schiffrin D. Discourse markers. Cambridge University Press (Cambridge), 1987. 
Sedgwick W.B. Sappho in Longinus (X 2, line 13). AJPh. 1948;69:197-200.

Scott J. Social Network Analysis: A Handbook, 2nd edition. Sage Publications (Los Angeles) 2000.

Sidwell K. Athenaeus, Lucian and Fifth-Century Comedy. Braund D. and Wilkins J. Athenaeus and his World. Exeter University Press (Exeter), 2000:136-52.

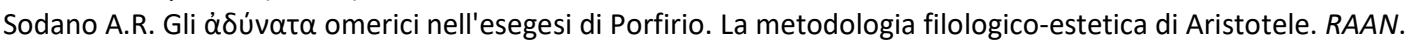
1965;40:227-278.

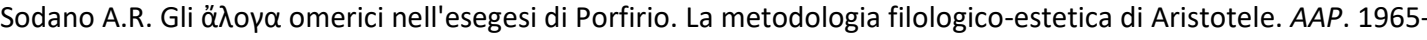
1966;15:205-239.

Stefani E.L. de. La fonte delle epistole III e VI di Eliano. SIFC. 1912;19:8-10.

Suárez de la Torre E. Motivos y temas en las cartas de amor de Filóstrato y Aristéneto. Fortunatae. 1991;1:113-132.

Szarmach M. Essai de reconstitution du Palamède d'Euripide. Meander. 1973;28:281-287.

Thesaurus Linguae Graecae ${ }^{\circledast}$ Digital Library. Ed. Maria C. Pantelia. University of California, Irvine. http://www.tlg.uci.edu.

Vargas Quesada B. and Moya Anegón F. Visualizing the structure of science. Springer-Verlag (New York) 2007.

Villari E. Une hypothèse sur les sources d'Athénée (Deipn. 120e-f) et de la «Vita Sophoclis» (663-5): Aristoxène, musicien et biographe. REG. 1996;109:696-706.

Volpe Cacciatore P. Temistio lettore di Plutarco. Pérez Jiménez A. and Bonner Titchener F. Historical and biographical values of Plutarch's works: Studies devoted to Professor Philip A. Stadter by the International Plutarch Society. Universidad de Málaga (Málaga), 2005:487-492.

Wasserman S. and Faust K. Social Network Analysis: Methods and Applications (Structural Analysis in the Social Sciences). Cambridge University Press (Cambridge) 1994.

Zecchini G. La cultura storica di Ateneo. Vita e pensiero (Milano), 1989.

Zeitlin F. Visions and revisions of Homer. Goldhill S. Being Greek under Rome. Cambridge University Press (Cambridge), 2001:195-266. 